\title{
Genetic admixture in pig population observed by microsatellite markers
}

\author{
Radoslav Židek', Daniela Jakabová2, Jozef Trandžík ${ }^{3}$, Ján Buleca Jr. ${ }^{4}$, Daniela Takáčová4 \\ and Rudolf Žitňan ${ }^{5}$ \\ ${ }^{1}$ SlovakUniversity of Agriculture, Nitra, Slovak Republic, ${ }^{2}$ Breeding Services SRS. E., Nitra, Slovak Republic, ${ }^{3}$ Constantine \\ the Philosopher University, Nitra, Slovak Republic, ${ }^{4}$ University of Veterinary Medicine and Pharmacy, Košice, Slovak \\ Republic, ${ }^{5}$ Animal Production Research Centre, Nitra, Slovak Republic
}

\begin{abstract}
The aim of presented study was estimation of genetic relationship within and between 3 mentioned pig breeds bred in the Slovak Republic. Genetic variability at 10 microsatellite loci (SW24, SO107, SO068, SW936, sw353, so386, so355, sw72, tnfb, and SO070) was analysed in 412 pigs of Landrace, Yorkshire and Slovak White Improved breeds. Variation amount of each population was measured with average number of alleles per locus, heterozygosities, polymorphism information content (PIC) value were calculated. Phylogenetic trees were constructed by UPGMA.

The average number of alleles per locus was 11.5, ranging from 7 (SW72) to 16 (SO068). The Slovak White Improved, Landrace and Yorkshire pig breeds showed out high degree of genetic diversity with mean expected heterozygosities of $0.720,0.697$ and 0.705 respectively. Genetic distance ranged from 0.060 between Yorkshire and Slovak White Improved to 0.203 between Landrace and Slovak White Improved breeds.

The scatter diagram from principal component displayed genetic differentiation among all three breeds. A Bayesian method was applied for individual assigning testing. On the base of our results the group of Slovak White Improved population was strongly mixed with Yorkshire breed and the group of all Landrace individuals was presented as enclosed population.
\end{abstract}

Keywords: pigs, microsatellites, genetic variability, biodiversity, admixture

\section{Zusammenfassung}

\section{Genetische Variabilität von Schweinepopulationen beurteilt mittels Mikrosatelliten-Loci}

Ziel der Untersuchung war die Schätzung der genetischen Beziehungen der drei in der Slowakischen Republik gezüchteten Schweinerassen Landrasse (L), Yorkshire $(Y)$ und Slowakisches Weißes Edelschwein (S). Diese Beziehungen wurden durch die Variabilität von 10 Mikrosatelliten-Loci (SW24, S0107, So68, SW936, SW 353, SO368, SO355, SW72, TNFB, S0070) beurteilt. Die Variation zwischen jeder Population wurde als durchschnittliche Anzahl von Allelen je Lokus gemessen. Heterozygotie und PIC Wert wurden berechnet. Die phylogenetischen Bäume wurden mit Hilfe von UPGMA konstruiert. Die durchschnittliche 
Anzahl an Allelen je Lokus betrug 11,5 in der Spannweite von 7 (SW72) bis 16 (SO068). Bei allen drei Schweinerassen fand sich eine hohe genetische Vielfalt mit Heterozygotiewerten von $S=0,720, L=0,697$ bzw. $Y=0,705$. Für die genetische Distanz ergaben sich Werte für Y zu S von 0.06 bzw. L zu S von 0,203. Ein Skaterdiagramm der Hauptkomponenten stellt die genetischen Unterschiede zwischen allen drei Rassen dar. Die individuelle Zuordnung erfolgte mit Hilfe der Bayesschen Methode. Die Ergebnisse belegen eine große Nähe der Rassen $\mathrm{Y}$ und $\mathrm{S}$, während sich $\mathrm{L}$ als geschlossene Population erwies.

Schlüsselwörter: Schweine, Mikrosatelliten, genetische Variabilität, Biodiversität, Mischung

\section{Introduction}

The current situation of pig breeds in Europe is marked by coexistence of many small populations of local breeds and relatively small number of intensively selected breeds (e. $\mathrm{g}$. Large White, Landrace and Pietrain) (Foulley et al. 2006).

Since early of the 20th century, number of pigs in the Slovak Republic has been drastically decreased due to their lower productivity level comparing to other imported commercial breeds. In our work we use allele length variation at microsatellite loci to investigate the genetic variation in the Slovak White Improved, Landrace and Yorkshire breeds.

Before World War I native Slovak white pigs have been crossbred with imported Yorkshire, Berkshire and Cornwall breeds. Later, there were extensive hybridizations with German White Improved (Deutsche Edelschwein) and German White Improved of Landrace type (Deutsche veredeltes Landschwein) as well as Polish, Swedish and Canadian Landrace. In the recent times, improved types of white pigs were unified to Slovak White Improved breed (Sambraus 2006). Assessment of Slovak breeds' population structure is an important task for animal genetic studies.

Yorkshire is an active outdoor breed. Their descendants could be found in all crossbreeding and rotational breeding programs using two or more breeds throughout the world. The sow component of commercial programmes usually contains half or even more of their blood (Briggs 1983).

The Landrace breed's development began with the native Landrace type. Native stock in the Slovak Republic was crossed with German, Danish, Dutch, Swedish and Belgian Landrace. In the Slovak Republic as well as in other countries, the $90 \%$ of all marketed pigs are crossbreds, but most attention is given to seedstock.

Pig genetic diversity studies were conducted by genotyping multiple microsatellite loci (Kim et al. 2005, Thuy et al.2006). Microsatellites are highly polymorphic co-dominant markers with simple identification, low mutation rates (Ellegren 1995) and uniform distribution throughout genome (Wintero et al. 1992). Microsatellite markers have been successfully used to assess the genetic structure and genetic diversity of breeds of domestic animals (Hall \& Bradley 1995, Wimmers et al. 1999, Aberle \& Distl 2004, Switonski 2004, Zsolnai et al. 2006, Kadlecik et al. 2004, Schwarz et al. 2005, Kasarda \& Kadlecik 2007, Slaska et al. 2008), except the genetic aspects also influence of environmental factors were observed in Slovak pig 
breeds (Hajduckova et al. 2009, Scirankova et al. 2009, Gancarcikova et al. 2009, Petrovic et al. 2009, Marcincak et al. 2003 and 2009).

In the presented study 10 pairs of microsatellite primers were used (Putnova et al. 2003). This microsatellite panel is generally used for parentage testing in Slovak Republic as well as for population genetic analyses. Used microsatellite markers were in accordance with the panel of microsatellites recommended by FAO and ISAG and were used for better exclusion ratio in middle European population.

Genetic structure observed by many viewing angles could be powerful tool for breeding programme optimisation. To get a complex view, different statistical methods have been used.

\section{Material and methods}

A total of 412 animals of 3 examined pig breeds raised in the Slovak Republic were distributed as follows: Landrace $(n=130)$; Yorkshire $(n=29)$; and Slovak White Improved $(n=253)$. Individuals used in this study represent the only breeding material allowed to create a Slovak swine population. All individuals included present core genetic material used for insemination and mating program in the Slovak Republic.

Genomic DNA was extracted from whole blood using the Wizard Genomic DNA Purification Kit according to a standard protocol (Promega). DNA microsatellite markers SW24, S0107, SO068, SW936, SW353, SO386, SO355, SW72, TNFB, and SO070 were combined in multiplex-polymerase chain reaction using fluorescently labelled primers (Putnova et al. 2003). The reactions were carried out on a thermocycler MJ Research (PTC 200). PCR products were separated on capillary sequencer $\mathrm{ABI} 310$ (Applied Biosystems). Fragment size analysis was performed with GeneScan 3.7 NT software (Applied Biosystems).

Variation amount of each population was measured with average number of alleles per locus and observed $\left(\mathrm{H}_{\mathrm{o}}\right)$, expected $\left(\mathrm{H}_{\mathrm{e}}\right)$ heterozygosity (Nei 1987) and PIC value (Botstein et al. 1980) were calculated with the POWERMARKER 3.23 (Liu \& Muse 2005). Population structure was evaluated by the hierarchical $F$ statistics $-F_{I S^{\prime}}, F_{I^{\prime}} F_{S T}$ (Weir \& Hill 2002) and $G_{S T}$ using GENETIX software package (Belkhir et al. 1996). Distance measures were estimated according to NEl et al. (1983). Phylogenetic trees were constructed by using of unweighted pair group method with the arithmetic average (Upgma, Sneath \& Sokal 1973) from distance using the POWERMARKER 3.23 (Liu \& Muse 2005) and visualized by DENDROSCOPE software 1.0.5 (Huson et al. 2007).

To represent geometric relationships among the pig breeds, a principal component analysis (PCA) was applied using gene frequencies of all variable loci by GENETIX software package (Belkhir et al. 1996).

Several studies have shown that microsatellites can be used to identify the population origin of an individual (Rannala \& Mountain 1997, Cornuet et al. 1999). According to Maudet et al. (2002), two approaches using observed population allele frequencies to assign individuals to a breed were compared. $A$ »direct « method similar to the one commonly used in livestock studies (Buchanan et al. 1994) and a simulation-based method that provides a level of certainity ( $P$-value) for each animal assigned (Cornuet et al. 1999) The assignment tests were carried out by the GENECLASS 2 software (Piry et al. 2004). The exclusion method was carried out using the Bayesian approach (Rannala \& Mountain 1997) which has showed better 
accuracy than the frequency- and distance-based methods (Cornuet et al. 1999, Koskinen 2003). Assignment of each individual was tested by the "leave one out« procedure (Efron 1983), what means that each individual was excluded from the data set when performing its assignment.

\section{Results and discussion}

The allele frequencies of 10 microsatellite loci were analysed in 412 pigs of three most common pig breeds raised in the Slovak Republic. A total of 115 alleles combined in 367 genotypes were observed at 10 loci. The average number of alleles per locus was 11.5, ranging from 7 (SW72) to 16 (SO068).

As shown in the Table 1, the Slovak White Improved, Landrace and Yorkshire pigs have exhibited a high degree of genetic diversity with mean expected heterozygosities of 0.720 , 0.697 and 0.705 , respectively. On the contrary to small allele and genotype number the Yorkshire breed has the top value of observed heterozygosity. Only Yorkshire breed shows no presence of inbreeding.

The overall $F_{15}$ values per locus ranged from 0.024 (SO355) to 0.043 (TBFB), showing an overall $F_{1 S}$ of 0.035 (Table 2). The $F_{S T}$ and $G_{S T}$ estimates of genetic differentiation were not similar for all microsatellites loci. The $F_{S T}$ values ranged from 0.092 (SO386) to 0.114 (SO107). The mean $\mathrm{F}_{\mathrm{ST}}$ value of 0.105 from all the loci indicated that $89.5 \%$ of the genetic variation was caused by differences among individuals and $10.5 \%$ only due to differentiation among the breeds. The mean $\mathrm{G}_{\mathrm{ST}}$ value (0.064) presents another view of analysed population and brings probably smaller differentiation among breeds.

Following swine breeds (represented by first letter of the breed name) were included in our study: S-Slovak White Improved, L-Landrace, Y-Yorkshire.

Table 1

Genetic variability computed separately for each observed breed

\begin{tabular}{lccccccr}
\hline Breed & Genotype & Sample size & Allele & $\mathrm{H}_{\mathrm{E}}$ & $\mathrm{H}_{\mathrm{O}}$ & PIC & \multicolumn{1}{c}{$\mathrm{F}_{\text {IS }}$} \\
\hline Slovak White Improved & 27 & 251 & 10.5 & 0.720 & 0.706 & 0.686 & 0.020 \\
Landrace & 20.9 & 130 & 8.7 & 0.697 & 0.642 & 0.661 & 0.082 \\
Yorkshire & 12 & 29 & 7.1 & 0.705 & 0.745 & 0.667 & -0.038 \\
Mean & 19.97 & 136.7 & 8.766 & 0.707 & 0.698 & 0.671 & 0.021 \\
\hline
\end{tabular}

Nei's $D_{A}$ genetic distance and mean $F_{S T}$ estimates between each pair of porcine population were computed (Table 2). The genetic distance ranged from 0.060 (between Yorkshire and Slovak White Improved) to 0.203 (between Landrace and Slovak White Improved). Pair wise $F_{\text {ST }}$ estimates ranged from 0.045 (between Yorkshire and Slovak White Improved) to 0.127 (between Landrace and Slovak White Improved). Computed $D_{A}$ and $F_{S T}$ corroborated our trees and PCA analysis. 


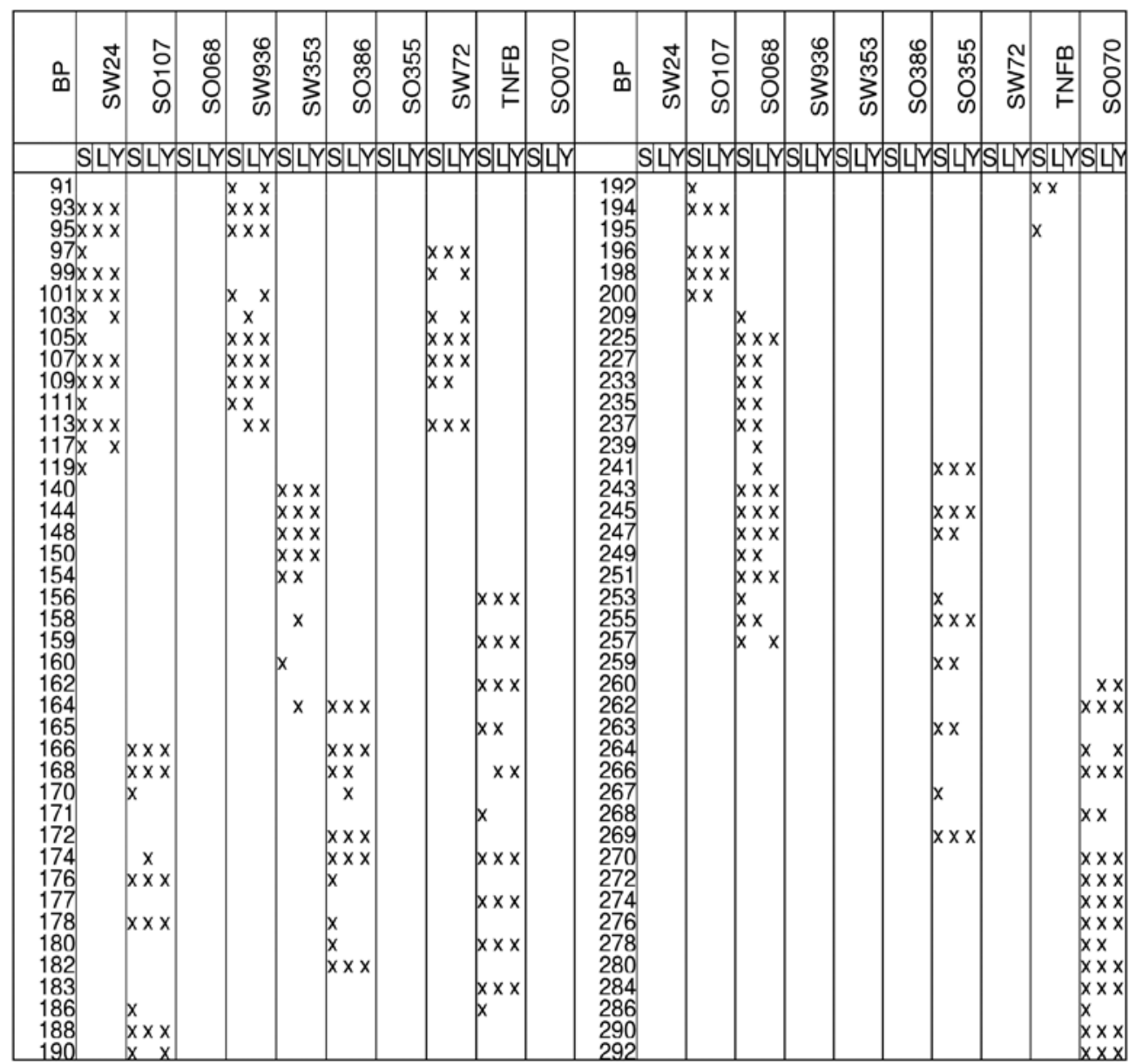

Figure 1

Number of alleles and molecular size for porcine microsatellite markers observed in three swine breeds.

Phylogenetic trees were constructed on the base of Nei's $D_{A}$ genetic distance computed for each possible combination of animals separately. Almost all Landrace breed individuals were grouped into the same branches. Group of Slovak White Improved breed was strongly mixed with Yorkshire pigs. Similar results show the relative position of all analysed animals defined by principal component factor scores based on correlation matrix from allele frequency of 10 microsatellites. The $x$ and $y$ axes represented $89.2 \%$ and $10.8 \%$ of the total variation, respectively. These axes separated the pig breeds into two blocks. Block I contains mostly Landrace breed and block II is created by mixture of Slovak White Improved and Yorkshire breeds. Differences between breeds included in block II are observable only on y axis. 
Table 2

Nei's $D_{A}$ genetic distance (below the diagonal) and mean $F_{S T}$ estimates (above the diagonal) between each pair of pig populations

\begin{tabular}{lccc}
\hline Breed & Slovak White Improved & Landrace & Yorkshire \\
\hline Slovak White Improved & - & 0.127 & 0.045 \\
Landrace & 0.203 & - & 0.112 \\
Yorkshire & 0.060 & 0.180 & - \\
\hline
\end{tabular}

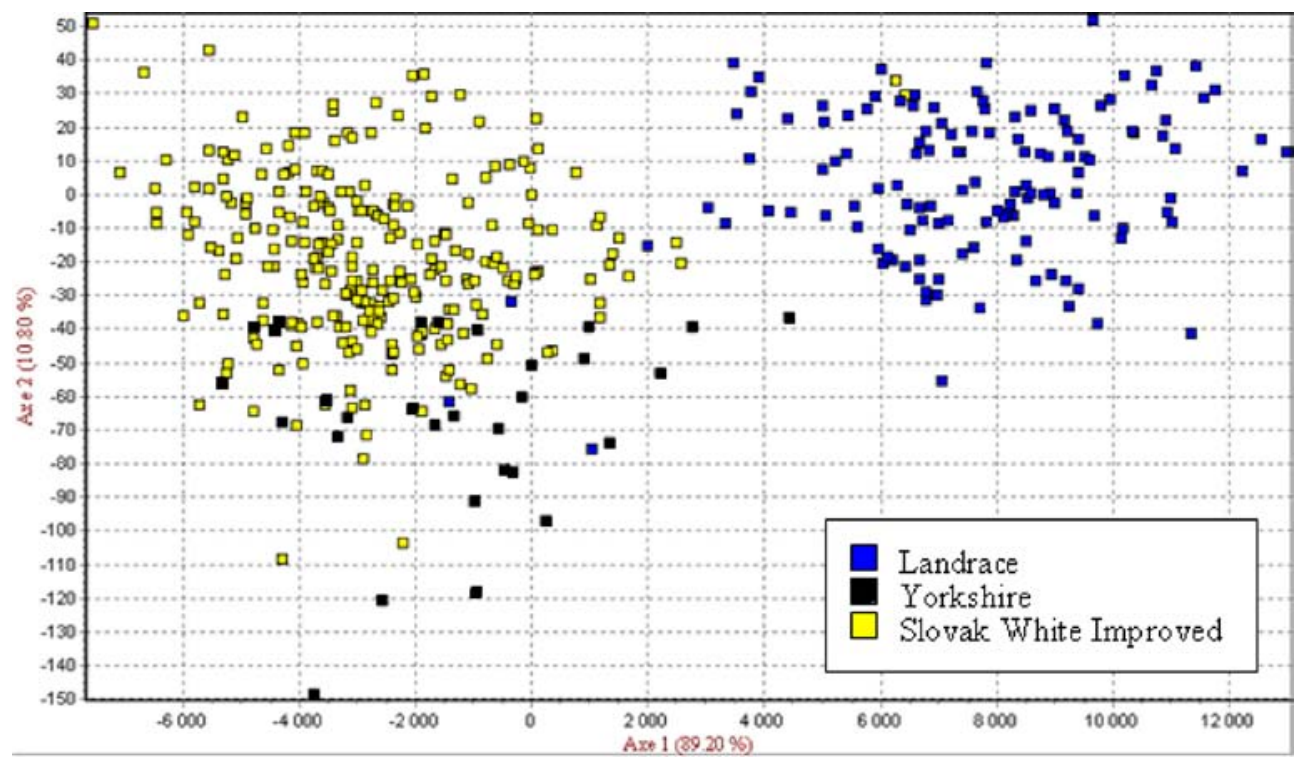

Figure 2

Scatter diagram showing relative position of 412 individuals defined by principal component factor scores based on correlation matrix from allele frequency of the 10 microsatellites.

Table 3

Breed assignment test results, showing the percentage of individuals correctly assigned using the "direct» approach or the »exclusion-simulation « approach using separately 10 microsatellite markers

Percentage of individuals correctly assigned

\begin{tabular}{|c|c|c|c|c|}
\hline \multirow[b]{2}{*}{ Item } & \multirow[b]{2}{*}{$\mathrm{n}$} & \multirow[b]{2}{*}{ Direct } & \multicolumn{2}{|c|}{$\begin{array}{c}\text { Exclusion-simulation } \\
\text { (reject population probability) }\end{array}$} \\
\hline & & & $P<0.10$ & $P<0.05$ \\
\hline Landrace & 130 & 95.38 & 73.85 & 72.31 \\
\hline Yorkshire & 29 & 72.41 & 3.45 & 0.00 \\
\hline Slovak White Improved & 253 & 78.65 & 30.83 & 26.09 \\
\hline
\end{tabular}

Table 3 shows the percentage of individuals correctly assigned to their population of origin. All individuals from observed breed were assigned to their breed of origin by using a direct approach, whereas the accuracy of assignment of individuals from Landrace, Yorkshire and Slovak White Improved breeds were 95.38, 72.41 and $78.65 \%$, respectively. By exclusion simulation (10.000 simulated individuals) on confidence level $P<0.10$ and $P<0.05$ results were 
significantly different. No Yorkshire pig was correctly assigned to Yorkshire breed on $P<0.05$ level, and only $26.09 \%$ of Slovak White Improved pigs were correctly assigned to their breed of origin.

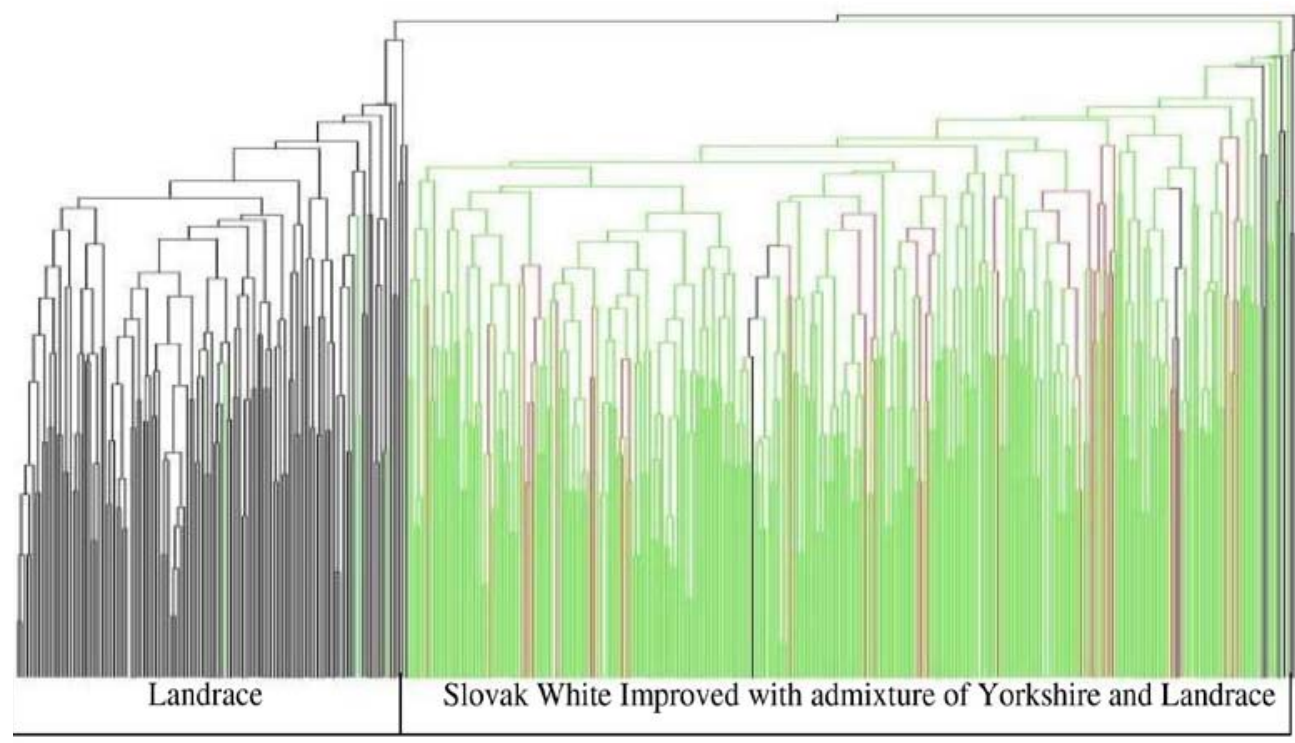

Figure 3

Dendrogram showing the genetic relationships among 412 pigs based on $D_{A}$ genetic distance (Nei et al. 1983)

There are many tools suitable for genetic variability observation. As a result of the FAO's recommendation and their availability through genomic mapping, microsatellites have been widely used to characterize genetic diversity (Barker 1999). In present study we have been dealing with the heterozygosity, genetic distance and admixture as an adequate measure of genetic diversity between selected breeds.

Figure 1 shows the fragment length and number of alleles for each microsatellite locus. Alleles unique to at least one breed were found for all microsatellite markers. According to Paszek et al. (1998) we cannot confirm specificity of allele 140 (SW353) for Landrace population. Number of alleles and allelic size range were compared to Korean, Chinese and Iberian pig breeds. Number of alleles for marker SO072 (7), SO070 (15), SW936 (10), SW24 (13) were similar to Iberian as well as Korean and Chinese population described by Fabuel et al. (2004) and Kim et al. (2005). Markedly higher number of alleles for each microsatellite markers described above was observed in Chinese indigenous pig breeds (Yang et al. 2003). The observed heterozygosity varied between 0.64 (Landrace) to 0.74 (Slovak White Improved), which represent typical value for European breeds. Observed heterozygosity in Slovak Landrace population is equal to Korean (0.62), Vietnamese (0.60) and German population (Kim et al. 2005, Thuy et al. 2006). Slovak Yorkshire according to another Yorkshire population presents higher value of observed heterozygosity. Analysed overall microsatellite loci heterozygosity ranged from 0.584 to 0.840 . These values are comparable to Pulawska breed (0.54-0.90) described by Babicz et al. (2003) and to Indian pigs (0.52-0.90) (Kaul et 
al. 2001). Mean value was equal to Iberian pig (0.69) (Fabuel et al. 2004) and just slightly higher than Chinese pig (0.609) (Yang et al. 2003). Inbreeding coefficients $\left(F_{15}\right)$ were higher in Landrace and Slovak White Improved breeds. Yorkshire population seems to be not affected by inbreeding.

Nei's $D_{A}$ genetic distance and mean $F_{S T}$ estimates between Landrace and Yorkshire breeds were 0.180 and 0.112 , respectively. These results are similar to Landrace and Yorkshire population in Korea and China (Kim et al. 2005). Small distance between Yorkshire and Slovak White Improved pig ( 0.060 and 0.045 ) caused specific result of UPGMA tree. Both breeds were grouped in the same branch and strongly admixed. Hypothesis, that Slovak White Improved breed is still closely related to Yorkshire pig is supported by PCA analysis. Percentage of individual pigs assigned to breed of origin using Bayesian approach shows inability of correct separation of observed breeds. Slovak White Improved population is strongly admixed with Slovak population of Yorkshire pig.

\section{Acknowledgements}

This work was supported by the Slovak Research and Development Agency under the contact No. APVV 20-063205 and by the scientific grant project VEGA No. 1/0046/10.

\section{References}

Aberle KS, Distl O (2004) Domestication of the horse: results based on microsatellite and mitochondrial DNA markers. Arch Tierz 47, 517-535

Babicz M, Kuryl J, Walkiewicz A (2003) Evaluation of the genetic profile of the Pulawska breed. J Appl Genet 44, 497-508

Barker JSF (1999) Conservation of livestock breeds diversity. AGRI 25, 33-43

Belkhir K, Borsa P, Chichi L, Raufaste N, Bonhomme F (1996) GENETIX 4.05, Windows software for population genetics. Laboratoire Génome, Populations, Interactions, DNRS UMR 5171, Université de Montpellier II, Montpellier, France. http://www.genetix.univ-montp2.fr/genetix/genetix.htm [last accessed 2.2.2011]

Botstein D, White RL, Skolnick M (1980) Construction of a genetic linkage map in man using restriction fragment length polymorphisms. Am J Hum Gen 32, 314-331

Briggs HM (ed) (1983) International Pig Breeds Encyclopedia. Elanco Products Company, Indiana, USA, 65

Buchanan FC, Adams LJ, Littlejohn RP, Maddox JF, Crawford AM (1994) Determination of evolutionary relationships among sheep breeds using microsatellite. Genomics 22, 397-403

Cornuet JM, Piry S, Luikart G, Estoup A, Solignac M (1999) New methods employing multilocus genotypes to select or exclude populations as origins of individuals. Genetics 153, 1989-2000

Efron B (1983) Estimating the error rate of a prediction rule: Improvement on cross-validation. J Am Stat Assoc 78, 316-331

Ellegren H (1995) Mutation rate at porcine microsatellite loci. Mamm Genome 6, 376-377

Fabuel E, Barragán C, Silió L, Rodriguez Mc, Toro Ma (2004) Analysis of genetic diversity and conservation priorities in Iberian pigs based on microsatellite markers. Heredity 93, 104-113

Foulley JL, Schriek MGM, Alderson L, Amigues Z, Bagga M, Boscher MZ, Brugmans B, Cardellino R, Davoli R, Delgado JV, Fimland E, Gandini GC, Glodek P, Groenen MAM, Hammond K, Halizius B, Heuven H, Joosten R, Martinez AM, Matassino D, Meyer JN, Peleman J, Ramos AM, Rattink AP, Russo V, Siggens KW, Vega-Pla $J$, Ollivier L (2006) Genetic diversity analysis using lowly polymorphic dominant markers: The example of AFLP in pigs. J Hered 97, 244-252 
Gancarcikova S, Buleca V, Zitnan R, Nemcova R, Scirankova L, Koscova J, Mudronova D, Hluchy M, Huska M (2009) Postnatal morphological development and production of short-chain fatty acids in the digestive tract of gnotobiotic piglets. Vet Med (Praha) 54, 156-168

Hajduckova V, Nemcova R, Mudronova D, Certik M, Kastel R, Gancarcikova S, Koscova J, Buleca V, Scirankova $L$ (2009) The influence on lipid metabolism in piglets of administration of lactobacilli and flaxseed with increased content of $\omega$-3 PUFA. Proc. Food and Function 2009 - Int. Sci. Conf. Nutraceuticals and Functional Foods, Zilina, Slovakia, 69

Hall SGJ, Bradley DG (1995) Conserving livestock breed diversity. Trends in Ecol Evol 10, 267-270

Huson DH, Dezulian T, Franz M, Rausch C, Richter DC, Rupp R (2007) Dendroscope: An interactive tree drawer. http://ab.informatik.uni-tuebingen.de/software/dendroscope [last accessed 2.2.2011]

Kaul R, Singh A, Vijh RK, Tantia MS, Behl R (2001) Evaluation of the genetic variability of 13 microsatellite markers in native Indian pigs. J Gen 80, 149-153

Kasarda R, Kadlecik O (2007) An economic impact of inbreeding in the purebred population of Pinzgau cattle in Slovakia on milk production traits. Czech J Anim Sci 52, 7-11

Kadlecik O, Kasarda R, Hetenyi L (2004) Genetic gain, increase in inbreeding rate and generation interval in alternatives of Pinzgau breeding program. Czech J Anim Sci 49, 524-531

Kim TH, Kim KS, Choi BH, Yoon DH, Jag GW, Lee KT, Chung HY, Lee HY, Park HS, Lee JW (2005) Genetic structure of pig breeds from Korea and China using microsatellite loci analysis. J Anim Sci 83, 2255-2263

Koskinen MT (2003) Individual assignment using microsatellite DNA reveals unambiguous breed identification in the domestic dog. Anim Genet 34, 297-301

Liu K, Muse SV (2005) PowerMarker: Integrated analysis environment for genetic marker data. Bioinformatics 21, 2128-2129

Marcincak S, Bystricky P, Turek P, Popelka P, Mate D, Sokol J, Nagy J, Durcak P (2003) The effect of natural antioxidants on oxidative processes in pork meat. Folia Vet 47, 215-217

Marcincak S, Nemcova R, Sokol J, Popelka P, Gancarcikova S, Svedova M (2009) Impact of feeding of flaxseed and probiotics on meat quality and lipid oxidation process in pork during storage, Slov Vet Res 46 (1), 13-8

Maudet C, Luikart G, Taberlet P (2002) Genetic diversity and assignment tests among seven French cattle breeds based on microsatellite DNA analysis. J Anim Sci 80, 942-950

Nei M (ed.) (1987) Molecular Evolutionary Genetics, Columbia University Press, New York, USA

Nei M, Tajima F, Tateno Y (1983) Accuracy of estimation phylogenetic trees from molecular data. J Mol Evol $19,153-170$

Paszek AA, Flickinger GH, Fontanesi L, Beattie CW, Rohrer GA, Alexander L, Schook LB (1998) Evaluating Evolutionary Divergence with Microsatellites, J Mol Evol 46, 121-126

Petrovic V, Novotny J, Hisira V, Link R, Leng L, Kovac G (2009) The impact of suckling and post-weaning period on blood chemistry of piglets, Acta Vet Brno 78, 365-371

Putnova L, Knoll A, Dvorak V, Dvorak J (2003) A novel porcine microsatellite panel for the identification of individuals and parentage control in the Czech Republic. Czech J Anim Sci 48, 307-314

Piry S, Alapetite A, Cornuet JM, Paetkau D, Baudiuin L, Estoup A (2004) GeneClass2: A Software for genetic assignment and first-generation migrant detection. J Hered 95, 536-539

Rannala B, Mountain JL (1997) Detecting immigration by using multilocus genotypes. Proc Natl Acad Sci USA 98, 9197-9201

Sambraus HH (ed.) (2006) Atlas of breeds of industrial animals, Brazda Publishing, Prague, Czech Republic [in Czech]

Scirankova L, Zitnan R, Nemcova R, Gancarcikova S, Buleca V, Koscova J, Mudronova D, Hajduckova V (2009) The influence of combination of probiotics culture and PUFA on morphometric parameters in conventional piglets. Proc. Food and Function 2009 - Int. Sci. Conf. Nutraceuticals and Functional Foods, Zilina, Slovakia, 91

Schwarz S, Presuhn U, Kalm E, Reinsch N (2005) Characterizing polymorphism and multiplex feasibility of 142 microsatellite markers from a commercial German Landrace line. Arch Tierz 48, 490-493 
Slaska B, Jezewska G, Zieba G, Pierczhala M (2008) Genetic variability and linkage of selected microsatellite markers in the Chinese raccoon dog. Arch Tierz 51, 187-198

Sneath PHA, Sokal RR (eds.) (1973) Numerical Taxonomy, WH Freeman \& Co, San Francisco, USA

Switonski M (2004) Marker genome maps of the sheep and goat. Arch Tierz 47 Special Issue, 4-9

Thuy NTD, Melichinger-Wild E, Kuss AW, Cuong NV, Bartenschlager H, Geldermann H (2006) Comparison of Vietnamese and European pig breed using microsatellites. J Anim Sci 84, 2601-2608

Weir BS, Hill WG (2002) Estimating F-statistics. Ann Rev Genet 36, 721-750

Wimmers K, Ponsuksili S, Schmoll F, Hardge T, Sonaiya EB, Schellander K, Horst P (1999) Application of microsatellite analysis to group chicken according to their genetic similarity. Arch Tierz 42, 629-639

Wintero AK, Fredholm M, Thomsen PD (1992) Variable (dG-dT)n.(dC-dA)n sequences in the porcine genome. Genomics 12, 281-288

Yang SL, Wang ZG, Liu B, Shang GX, Zhao SH, Yu M, Fan B, Li MH, Xiong TA, Li K (2003) Genetic variation and relationships of eighteen Chinese indigenous pig breeds. Genet Sel Evol 35, 657-671

Zsolnai A, Radnoczy L, Fesus L, Anton I (2006) Do Mangalica pigs of different colours really belong to different breeds. Arch Tierz 49, 477-483

Received 14 September 2009, accepted 4 November 2010.

Corresponding author:

Ján Buleca

email: buleca@gmail.sk

University of Veterinary Medicine and Pharmacy, Institute of Animal Husbandry, Komenského 73, 04013 Košice, Slovak Republic 